\title{
HEREDITARY NON-POLYPOSIS COLORECTAL CANCER (LYNCH SYNDROME) PADA WANITA UMUR 16 TAHUN
}

\author{
Asril Zahari, Sudiyatmo \\ Sub-Bagian Bedah Digestif Fakultas Kedokteran Universitas Andalas / \\ RS. Dr. M. Djamil Padang \\ email : majalahkedokteranandalas@gmail.com
}

\begin{abstract}
Abstrak
Kanker kolorektal menduduki peringkat ketiga jenis kanker yang paling sering terjadi di dunia. Sekitar 3\% kasus kanker kolorektal merupakan jenis hereditary non polyposis colorectal cancer (HNPCC)/Lynch syndrome, yang sering muncul pada usia muda. Dilaporkan satu kasus di rumah sakit Dr. M. Djamil Padang, wanita berumur 16 tahun dengan keluhan nyeri perut kanan bawah. Didapatkan riwayat penyakit serupa pada kakek, bibi pasien dan enam anggota keluarga yang lain. Pada pemeriksaan fisik abdomen teraba massa dengan konsistensi keras dan terfiksir. Pada kolonoskopi dan biopsi ditemukan tumor jenis adenocarcinoma colon moderatly differentiated di fleksura hepatika dan polip di kolon sigmoid. Berdasarkan kriteria Amsterdam pasien didiagnosa Lynch syndrome. Pada Pasien dilakukan subtotal kolektomi, anastomose ileorectal dan kemoterapi ajuvan. Identifikasi genetik sedang dikerjakan untuk melihat adanya kelainan genetik pada pasien. Pasien melakukan skrining berkala untuk mencegah kanker HNPCC jenis yang lain.
\end{abstract}

Kata kunci : Hereditary non polyposis colorectal cancer, Lynch syndrome, Microsatellite instability, skrining.

\begin{abstract}
Carcinoma colorectal is the third most common type of cancer that occurs in the world. About 2\%-3\% of cases of colorectal cancer is hereditary nonpolyposis colorectal cancer (HNPCC)/Lynch syndrome, which often appear at a young age. Amsterdam and Bethesda criteria have been used to identify patients with Lynch syndrome.

one case was reported at the Dr. M. Djamil Padang hospital, a 16-year-old girl with right lower abdominal pain. Obtained a history of similar disease in grandparents, aunts and six other family members. On physical examination found palpable fixed abdominal mass with hard consistency in the lower right abdomen. At colonoscopy and biopsy found a moderatly differentiated adenocarcinoma colon type at the hepatic flexure and the sigmoid colon polyp. Based on the Amsterdam criteria, patients diagnosed with HNPCC/Lynch syndrome. Patients treated with subtotal colectomy, ileorectal anastomose and adjuvant chemotherapy.
\end{abstract}


Genetic identification is underway to see any genetic abnormalities. Patients be screened regularly to prevent other types of cancer HNPCC.

Key word : Hereditary non-polyposis colorectal cancer, Lynch syndrome, Microsatellite instability, screening. 


\section{PENDAHULUAN}

Kanker kolorektal (KKR) menduduki peringkat ketiga jenis kanker yang paling sering terjadi dan merupakan penyebab kematian peringkat ketiga di dunia. ${ }^{(1)}$ Menurut data depkes 28,17\% kanker di Indonesia adalah KKR. Di rumah sakit M. Djamil Padang tercatat 257 pasien KKR pada periode tahun $2002-2007$. $^{(2)}$

Sekitar 2\%-3\% pasien dari seluruh KKR merupakan Hereditary nonpolyposis colorectal cancer (HNPCC). HNPCC yang juga dikenal dengan Lynch syndrome, ditandai dengan peningkatan kemungkinan terjadinya $\mathrm{KKR}$, dan tumor lainnya seperti tumor pada endometrium, ovarium, lambung, usus halus, hepatobilier, pankreas, ginjal, otak atau kulit. Pada jenis ini KKR terjadi pada umur yang lebih muda (kisaran umur 45 tahun bahkan lebih muda). Secara genetik sindrom ini diturunkan secara autosomal dominan, dan ketika sindrom ini terdiagnosa, pasien memiliki kemungkinan untuk menderita kanker kolorektal sebesar $70 \%-80 \%$. $^{(3,4)}$

Penamaan Lynch syndrome dan HNPCC telah lama digunakan secara bersamaan dan bergantian. Namun beberapa penulis menyebutkan bahwa istilah "nonpolyposis" pada HNPCC kurang tepat dan lebih menyukai penyebutan Lynch syndrome. Hal ini karena dijumpainya polip adenomatous sebagai bagian dari proses karsinogenesis pada pasien dengan sindrom ini. Disamping adanya kanker selain KKR yang bisa muncul pada pasien Lynch syndrome. Sementara penulis lain menganjurkan penyebutan Lynch syndrome ditujukan pada keluarga dengan bukti yang kuat adanya mutasi gen mismatch repair (MMR). ${ }^{(4,5)}$

Walaupun informasi mengenai genetik dan garis keturunan Lynch syndrome telah teridentifikasi dengan cukup baik, manifestasi klinis dari penyakit ini tidaklah spesifik. Diagnosa hanya didasarkan pada riwayat kanker pada keluarga. Ketika diagnosa klinik pada sebuah keluarga menunjukkan Lynch sindrome, maka segera dianjurkan langkah-langkah pencegahan dan skrining. ${ }^{(3,4)}$ Penulis mengajukan kasus kanker kolon pada pasien Lynch syndrome yang berumur 16 tahun.

\section{ANALISA KASUS}

Seorang wanita berumur 16 tahun datang ke poli bagian bedah rumah sakit Dr. M. Djamil Padang pada pertengahan bulan Agustus 2010 dengan keluhan utama nyeri perut kanan bawah sejak dua bulan sebelumnya. Nyeri perut meningkat sejak dua minggu terakhir. Benjolan dirasakan diperut kanan bawah sejak 2 bulan yang lalu. Nafsu makan berkurang sejak sakit dan disertai penurunan berat badan \pm 5 $\mathrm{kg}$ dalam 2 bulan terakhir. Frekuensi buang air besar (BAB) tidak teratur, umumnya BAB tiap 2-3 hari sekali dengan konsisitensi lunak. Didapatkan riwayat keluhan yang sama pada kakek, bibi dan lima anggota keluarga yang lain. Pada pemeriksaan fisik abdomen tampak benjolan di regio lumbal dekstra, teraba massa dengan ukuran $\pm 9 \times 6 \times 3$ $\mathrm{cm}$, dengan konsistensi keras, bernodul dan terfiksir disertai dengan nyeri tekan. Pada barium enema tampak gambaran filling defect (apple core) dengan penyempitan sentral di proksimal kolon tranversum, batas tak tegas, tepi irreguler dengan pelebaran kolon proksimal, kesan : sugestif $\mathrm{Ca}$ proksimal kolon tranversum (fleksura hepatika). Pada kolonoskopi dan biopsi didapatkan tumor di fleksura hepatica colon dan polip pedunculated di sigmoid, pada biopsi tumor didapatkan adenocarcinoma colon moderatly differentiated. Pada CT Scan tampak lesi isoden di proyeksi colon ascenden 
sehingga lumen colon ascenden bening para aorta, disimpulkan menyempit dan dinding tebal (ireguler), carcinoma colon stadium III A (Dukes terdapat pembesaran kelenjar getah $\mathrm{C}$ ).
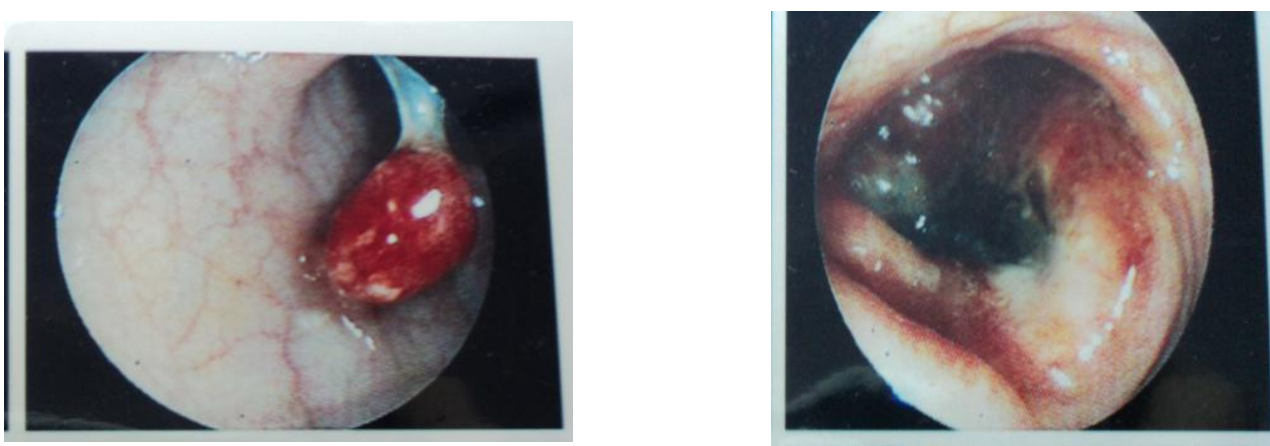

Gambar 1. Tampak massa tumor pada fleksura hepatika dan polip pedunculated di sigmoid

Berdasarkan evaluasi klinik pasien didiagnosa dengan karsinoma kolon stadium III A (Dukes C), polip pedunculated di sigmoid. Secara klinis menurut kriteria Amsterdam pasien termasuk dalam kelompok Hereditary nonpolyposis colorectal cancer (HNPCC)/ Lynch syndrome. Pada pasien dilakukan subtotal kolektomi dan anastomose ileorectal. Hasil pemeriksaan patologi anatomi pada sediaan tumor didapatkan jenis adenocarcinoma colon moderatly differentiated. Sebagai ajuvan terapi pasien dikemoterapi dengan regimen 5-Fluorouracil, Leucoverin, dan Oxaliplatin. Pasien telah menjalani analisa genetik dan program skrining untuk pencegahan kanker HNPCC jenis yang lain.

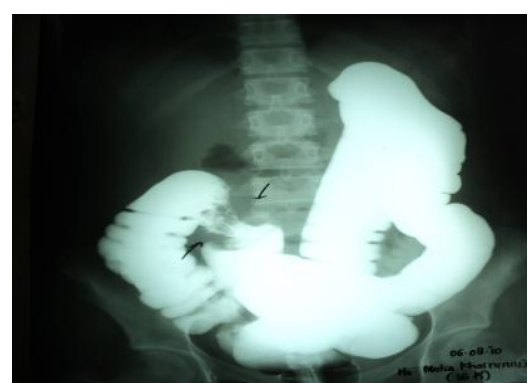

Gambar 2. Gambaran filling defect (apple core) dengan penyempitan sentral di proksimal kolon tranversum (fleksura hepatika).

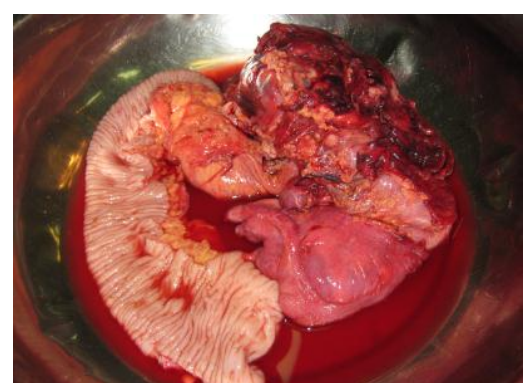

Gambar 3. Tumor pasca subtotal kolektomi, tampak tumor di proksimal kolon transversum. 
Pasien terakhir kali kontrol di poli bedah rumah sakit Dr. M. Djamil padang pada pertengahan Januari 2011. Pasien tidak lagi merasakan keluhan yang berhubungan dengan saluran pencernaan, memiliki nafsu makan yang baik dan merasa sehat. Pasien telah kembali menjalani aktivitasnya sebagai pelajar.

\section{DISKUSI}

Diagnosa HNPCC/Lynch syndrome pada pasien ini ditegakkan melalui analisa riwayat penyakit pada keluarga pasien. Internasional Collaborative Group on Hereditary Nonpolyposis Colorectal Cancer (ICGHNPCC) menetapkan kriteria diagnosa HNPCC yang dikenal dengan kriteria Amsterdam I dan II. Kriteria ini cukup spesifik dan mudah diterapkan. $^{(3,5)}$

Tidak semua keluarga dapat teridentifikasi Lynch syndrome melalui kriteria Amsterdam. Keluarga dengan jumlah anggota yang sedikit dan dengan riwayat penyakit yang sulit digali akan tersingkirkan jika mengunakan kriteria ini. Sehingga dikembangkanlah kriteria Bethesda. Walaupun tingginya biaya atau terbatasnya peralatan rumah sakit untuk melakukan analisa genetik pada pasien KKR, mayoritas penulis tetap menganjurkan penggunaan kriteria Bethesda untuk mengidentifikasi pasien yang akan menjalani analisa genetik. . $^{(6)}$

Tabel 1. Kriteria Amsterdam dan Bethesda ${ }^{(5,6)}$

\section{Kriteria Amsterdam :}

- Minimal tiga anggota keluarga dengan KKR atau jenis kanker HNPCC yang lain (endometrium, ovarium, saluran kencing, usus dan lambung)

- Satu anggota keluarga yang terkena memiliki anggota keluarga tingkat satu lain yang terkena

- Dua generasi terpengaruh

- Salah satu anggota keluarga didiagnosa dengan KKR sebelum usia 50 tahun

\section{Kriteria Bethesda :}

- Pasien KKR terdiagnosa sebelum umur 50 tahun

- Pasien KKR dengan satu anggota keluarga tingkat pertama yang menderita kanker HNPCC jenis lain sebelum umur 50 tahun

- Pasien KKR dengan dua atau lebih anggota keluarga tingkat pertama atau tingkat kedua yang menderita kanker HNPCC

- Pasien dengan kanker kolon proksimal dengan pola undifferentiated yang terdiagnosa sebelum 45 tahun

- Pasien KKR dengan diagnosa fenotip MSI-H sebelum umur 60 tahun

- Pasien dengan adenoma sebelum umur 40 tahun

$\begin{array}{lll}\text { Beberapa penulis lain } & \text { walaupun mereka telah menjalani } \\ \text { menyebutkan bahwa terdapat } & \text { konseling dan mengerti pentingnya } \\ \text { keterbatasan saat menggunakan kriteria } & \text { skrining tersebut. Pasien KKR terlebih } \\ \text { Bethesda, yaitu adanya kendala dalam } & \text { dahulu meninggal dunia sebelum } \\ \text { skrining genetik MSI-H. Pada faktanya } & \text { menjalani analisa genetik. Berdasarkan } \\ \text { mayoritas pasien KKR tidak menjalani } & \text { beberapa penelitian kohort, mereka } \\ \text { skrining genetik karena berbagai alasan, } & \text { menyimpulkan pentingnya mengggali }\end{array}$


riwayat keluarga pasien KKR untuk mendiagnosa secara klinis pasien-pasien
Lynch syndrome. $^{(7)}$

\section{Pedigree}

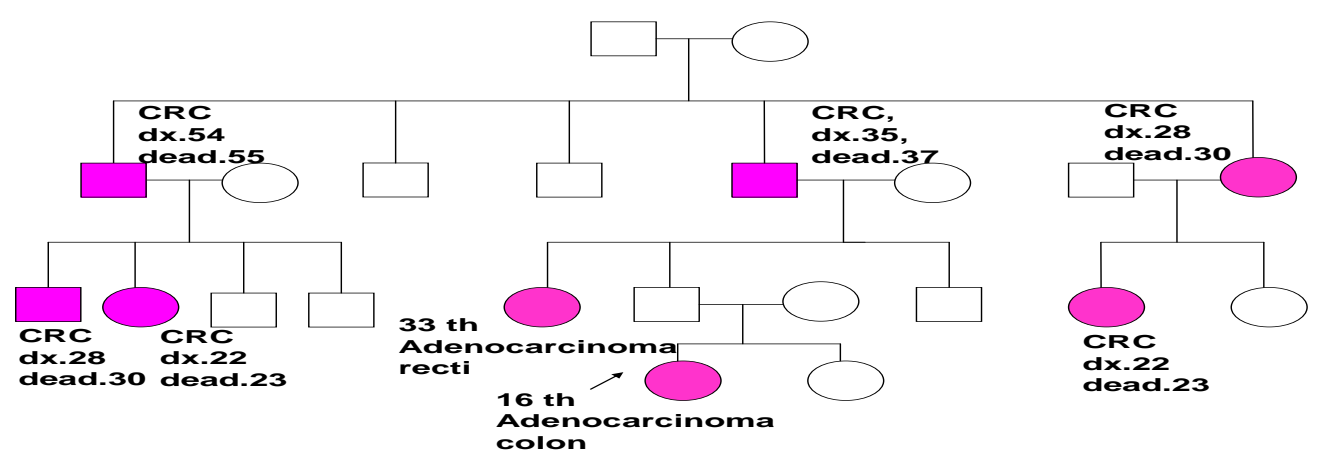

Gambar 4. Silsilah keluarga (pedigree) menunujukkan kejadian KKR pada beberapa anggota keluarga pasien. Sebagian besar penyakit terdiagnosa pada umur yang relatif muda. Keterangan : "dx" umur pasien terdiagnosa, "dead" umur pasien meninggal.

Berdasarkan kriteria amsterdam dan Bethesda pasien termasuk dalam Lynch syndrome, karena :

- Pasien dengan dua anggota keluarga tingkat kedua (kakek dan bibi) terdiagnosa KKR dan lima anggota keluarga lainnya juga menderita KKR dan dua generasi terpengaruh

- Lebih dari satu anggota keluarga yang didiagnosa KKR sebelum usia 50 tahun

- Pasien terdiagnosa KKR sebelum umur 50 tahun

- Pasien dengan tumor di kolon proksimal dan polip adenoma

Penulis mendapatkan data medis yang memadai untuk pasien dan bibinya. Keterangan diagnosa KKR, umur terdiagnosa dan umur meninggal berdasarkan wawancara mendalam terhadap keluarga pasien dan menggali riwayat penyakit pada anggota keluarga yang lain. Melalui analisa pedigree dapat dilihat adanya kecenderungan munculnya KKR pada usia muda. Sebagian besar keluarga yang menderita KKR tidak mendapatkan pengobatan yang baik. Hal ini disebabkan anggota keluarga yang tidak ingin berobat ke rumah sakit dan tingginya kepercayaan terhadap pengobatan tradisional.

Beberapa literatur menyebutkan bahwa 2/3 lokasi kanker pada HNPCC terdapat pada kolon proksimal. $^{(3,11)}$ Penelitian Ahmad M, et al menunjukkan $78 \%$ pasien kanker kolorektal usia muda berada pada stadium lanjut (Dukes $\mathrm{C}$ dan D). Penentuan stadium menunjukkan pasien berada pada stadium IIIA atau Dukes C. Pemeriksaan kolonoskopi yang didukung dengan barium enema merupakan alat diagnostik utama pada kanker kolorektal. Sementara pemeriksaan CT-Scan dilakukan untuk menentukan stadium sebelum operasi. $^{(1,8)}$

Pada pasien ini dilakukan subtotal kolektomi dengan anastomose ileorectal. Reseksi luas pada pasien KKR masih dalam perdebatan. Beberapa ahli menganjurkan subtotal kolektomi dengan anastomose ileorectal pada pasien Lynch syndrome, karena didapatkan angka harapan hidup yang lebih baik pada pasien yang diterapi dengan subtotal kolektomi. Beberapa penulis juga 
menyebutkan bahwa subtotal kolektomi dengan anastomose ileorectal akan meningkatkan kualitas hidup pasien Lynch syndrome karena verkurangnya kebutuhan mereka terhadap kolonoskopi dan ancaman munculnya tumor sekunder. ${ }^{(1,4,5)}$

\section{Diagnosa Genetik HNPCC}

Ketika pasien telah terdiagnosa secara klinis Lynch syndrome, maka pada keluarga pasien tersebut perlu dilakukan analisa genetik. Secara umum terdapat beberapa perubahan genetik pada KKR, yaitu onkogen (Kras) dan tiga tumor suppressor gene (APC, DPC4, dan p53). Namun beberapa penelitian menunjukkan bahwa instabilitas genome menjadi dasar utama terjadinya Lynch syndrome jika dibandingkan onkogen ataupun kelainan tumor suppressor gene. Adanya mutasi gen pada DNA mismatch repair (MMR) memicu terjadinya instabilitas genome dalam bentuk microsatellite instability. ${ }^{(4,9-11)}$

Pada $80 \%$ kasus KKR merupakan jenis stabil mikrosatelit, yang artinya tidak didapatkan kerusakan pada MMR. Sementara $20 \%$ lainnya disertai adanya kerusakan MMR yang bertugas memperbaiki kesalahan yang terjadi pada pasangan basa pada susunan gen. Adanya segmen kecil dari microsatellite instability merupakan hasil dari mutasi salah satu dari empat gen MMR, yaitu MLH1, MSH2, MSH6 dan PMS2. ${ }^{(9,11,12)}$

Terdapat beberapa tes genetik untuk mengidentifikasi lynch syndrome, antara lain :

- Microsatellite instability test (MSI), tes skrining untuk Lynch syndrome. Dilakukan dengan mikrodiseksi pada jaringan tumor dan diperluas hingga ke jaringan yang sehat. Kemudian dilakukan ekstraksi DNA pada kedua sampel dan polymerase chain reaction pada beberapa regio microsatellite. ICGHNPCC memberikan tiga klasifikasi untuk hasil tes ini: High-instability (MSI-H) jika $\geq$ $30 \%$ lebih marker tidak stabil, Low-instability (MSI-L) jika instabilitas hingga 30\%, Absentinstability jika tidak terjadi ketidakstabilan. Lebih dari $90 \%$ pasien Lynch syndrome mengalami High-instability (MSI-H) pada tumornya. ${ }^{(3,4,8,10)}$

- Immunohistokimia pada protein gen DNA-repair (IH). Jaringan normal mengekspresikan protein MLH1 dan MSH2 dalam jumlah yang banyak di nukleus. Mutasi pada gen akan mengurangi kadar MLH1 dan MSH2, dan pada 80\%-90\% kasus HNPCC terjadi penurunan kadar MLH1 dan $\mathrm{MSH} 2$ atau tidak adanya IH..$^{(4,10,11)}$

- Cara analisa yang lain dapat dilakukan dengan DNAsequencing, karena tingkat sensitifitas dan spesifisitasnya yang tinggi tes ini merupakan standar baku untuk mendeteksi adanya mutasi gen pada Lynch syndrome. Tes ini membandingkan pasangan basa pada sebuah gen melalui sampel darah. Namun teknik ini cukup mahal dan memakan waktu. ${ }^{(3)}$

\section{Skrining Anggota Keluarga}

Anggota keluarga Lynch syndrome memiliki faktor risiko yang lebih besar untuk mengalami jenis kanker yang lain. Vasen et al, menyebutkan besarnya risiko tersebut yaitu; risiko KKR 24\%-75\%, kanker endometrium $27 \%-71 \%$, ovarium $3 \%$ $13 \%$, lambung $2 \%-13 \%$, saluran 
kemih 1\%-12\%, usus halus 4\%-7\%, otak $1 \%-4 \%$, dan hati dan saluran empedu $2 \%$. $^{(4)}$

Terkait dengan faktor risiko tersebut, International Collaborative Group on HNPCC merekomendasikan skrining pada anggota keluarga pasien Lynch syndrome. Skrining juga dilakukan pada organ-organ selain usus besar yang masuk dalam kelom-pok Lynch syndrome.

Tabel 2. Rekomendasi ICG-HNPCC untuk deteksi awal anggota keluarga $\operatorname{HNPCC}^{(4,5,10)}$

\begin{tabular}{llll}
\hline Organ & Pemeriksaan & Umur & Frekuensi \\
\hline Kolon \& Rektum & Kolonoskopi & $20-25$ & Per 2 tahun \\
Endometrium & USG endovaginal, & $30-35$ & $1-2$ tahun \\
Ovarium & pemeriksaan gnikologi & & \\
Urogenital & USG pelvis dan CA-125 & $30-35$ & $1-2$ tahun \\
Lambung & USG & $30-35$ & $2-3$ tahun \\
\hline
\end{tabular}

Lima bulan pasca operasi kondisi pasien dalam keadaan sehat. Pasien masih tetap kontrol dan telah menyelesaikan kemoterapi yang ke VI. Namun pasien masih tetap dianjurkan untuk skrining, karena kemungkinan munculnya kanker HNPCC jenis lain seperti kanker endometrium.

\section{KESIMPULAN}

Telah dilaporkan seorang pasien wanita muda dengan kanker kolon pada keluarga HNPCC/Lynch syndrome. Pada pasien telah dilakukan terapi operatif dan ajuvan kemoterapi. Selanjutnya perlu dilakukan tes dan konseling genetik untuk memperkuat diagnosa klinik HNPCC/Lynch syndrome pada pasien ini. Pemeriksaan skrining rutin sangat dianjurkan mengingat besarnya risiko terhadap kanker HNPCC baik kolon maupun ekstrakolon.

\section{KEPUSTAKAAN}

1. Zahari A. Deteksi dini, diagnosa, dan penatalaksanaan kanker kolon dan rektum. Majalah kedokteran Andalas 2008;98-121.
2. Zahari A, Rustam R, Luthfi A. Gambaran karakteristik dasar penderita karsinoma kolorektal di RS Dr. M. Jamil Padang tahun 2002-2007. Universitas Andalas / SMF bedah RS. M. Djamil Padang.

3. Silva RE, Garicochea B, Cotti G, Maranho IC, Cutait R. Hereditary nonpolyposis colorectal cancer identification and surveillance of high-risk family. Clinics 2005; 60(3): 251-6.

4. Al-Sukhni W, Aronson M, Gallinger S. Hereditary colorectal cancer syndromes: Familial Adenomatous Polyposis and Lynch Syndrome. Surgical Clinics of North America 88 (2008) 81944.

5. Vasen HF, Moslein G, Alonso A, et al. Guidelines for the clinical management of Lynch syndrome (hereditary non-polyposis cancer). J Med Genet 2007;44(6):353-62.

6. Merg A, Lynch HT, Lynch JF, et al. Hereditary colorectal cancerd 
Part II. Curr Probl Surg 2005; 42(5):267-334.

7. Umar A, Boland R, Terdiman JP. Revised Bethesda Guidelines for Hereditary Nonpolyposis Colorectal Cancer (Lynch Syndrome) and Microsatellite Instability. J Natl Cancer Inst 2004; 96: $261-8$.

8. Ahmad M, et al. Jamal-ud-Din, Qayum A, Afridi V. Young colorectal patients present with advance stage disease. Journal of Medical Sciences 2006;14: 51-4.

9. Gryfe R, Kim H, Hsieh ETK, et al. Tumor microsatellite instability and clinical outcome young patients with colorectal cancer. N Engl J Med 2000; 342: 69-77.

10. Datta RV, et al. Genetic and Phenotypic Corelates of colorectal cancer in young patients. $\mathrm{N}$ Eng $\mathrm{J}$ Med 2000; 342:137-8.

11. Corleto VD, Zykaj E, Mercantini P, et al. Is colonoscopy sufficient for colorectal cancer surveillance in all HNPCC patients?. World J Gastroenterol 2005; 11(47): 754144.

12. Zhou Y, Boardman LA, Miller RC. Genetic testing for young-onset colorectal cancer: case report and evidence-based clinical guidelines. Radiol Oncol 2010; 44(1): 57-61. 